\title{
Spatial distribution of mollusks in the intertidal zone of sheltered beaches in southeastern of Brazil
}

\author{
Eliane P. de Arruda ${ }^{1,2} \&$ A. Cecilia Z. Amaral ${ }^{2}$
}

\begin{abstract}
${ }_{1}$ Programa de Pós-Graduação, Departamento de Zoologia, Instituto de Biociências, Universidade de São Paulo. E-mail: lili_arruda@yahoo.com.br

${ }^{2}$ Departamento de Zoologia, Instituto de Biologia, Universidade de Campinas. Caixa Postal 6109, 13083-970, Campinas, São Paulo, Brasil.
\end{abstract}

\begin{abstract}
The spatial distribution of mollusks in the intertidal zone was examined monthly from August 1995 through July 1997, in Enseada, Barra Velha and Araçá beaches in southeastern of Brazil. One study sector was selected in Enseada and Barra Velha, and two sectors in Araçá (Araçá I and Araçá II). The sectors were $10 \mathrm{~m}$ wide and equivalent in length to the width of the intertidal zone. Each sector was divided into three horizontal levels: lower, middle and upper, where the samples were taken with a cylinder corer with a base area of $0.16 \mathrm{~m}^{2}$. In order to characterize the intertidal environment in these areas, some environmental variables were analyzed. In general, the mollusks were distributed in the sectors as follows: Enseada - Olivella minuta (Link, 1807) in the lower level and Tagelus plebeius (Lightfoot, 1786) in the upper level; Araçá I - O. minuta in the lower level, Tellina lineata Turton, 1819 and Anomalocardia brasiliana (Gmelin, 1791) in the middle levels; Araça II - Cerithium atratum (Born, 1778) in the lower level, 0 . minuta in the lower and middle levels, and $A$. brasiliana and Corbula caribaea Orbigny, 1842 in the middle level; Barra Velha - Tagelus divisus (Spengler, 1794), Lucina pectinata (Gmelin, 1791) and Tellina versicolor De Kay, 1843 in the lower level, and A. brasiliana and Macoma constricta (Brugüìere, 1792) in the upper level. The intertidal zone of the study sectors could be divided into two biological zones: the upper zone, where $T$. plebeius, $A$. brasiliana and $M$. constricta were more abundant; and the lower zone, where $O$. minuta, $C$. atratum, $T$. lineata, $T$. versicolor, $C$. caribaea, $T$. divisus and $L$. pectinata were abundant.
\end{abstract}

KEY WORDS. Caraguatatuba Bay, intertidal zone, mollusk, São Sebastião Channel, sheltered beach, spatial distribution.

Knowledge of the patterns of species distribution is important in understanding how environmental factors influence this distribution. In environments with wide variations in physical characteristics such as beaches or sandflats, community structure is determined by their morphodynamic state. The distribution of the macrofauna is the result of the relationships among environmental factors and species characteristics. The community structure and intertidal distribution of the macroinfauna have been related to abiotic factors such as grain size (Jaramillo \& GonZalez 1991, McLachlan 1996), wave action (Brown \& McLachlan 1990), water content (WENDT \& McLachlan 1985), and temperature and salinity of the interstitial water (KоH \& SHIN 1988). Biological factors such as recruitment, predation and competition are also of key importance in the establishment and maintenance of zonation (McLachlan \& JARAMILLO 1995). Therefore, zonation of the species is maintained by physical factors associated with biological interactions. It is unlikely that a single factor will explain patterns of distribution, since a species can occupy morphologically distinct habitats. The determination of macrofauna distribution in sandy beaches is quite difficult, because of the great instability of environmental conditions and because most organisms live within the sediment (AMARAL et al. 1990).

Several attempts have been made to construct zonation schemes for sandy beach macro-infauna, either for worldwide application, or at least for littoral areas over wide latitudinal ranges. The most important zonation schemes for macroinvertebrates in sandy beaches were proposed by DAHL (1952) and Salvat (1964), and have been used up to the present for comparative studies of spatial distribution of the macrofauna. However, JARAMILLO et al. (1993), studying intertidal zonation of macrofauna over a range of exposed sandy beaches in southcentral Chile, showed that different beach types may support different intertidal macroinfauna zonation patterns. 
In Brazil, most studies of spatial distribution of benthic macrofauna in sandy beaches have been done in the south and southeast. Corbisier (1991), Netto \& LANA (1995) and Borzone et al. (1996) worked with zonation of macrofauna in beaches of different morphodynamic types. The zonation patterns suggested by DAHL (1952) and SALVAT (1964) were compared to patterns in Barranco Beach by SouzA \& Gianuca (1995), and in São Francisco Beach by Rizzo \& Amaral (2001). Lopes \& SchaefferNovelui (1992), Borzone (1994) and Denadai et al. (2001) studied the community structure and spatial distribution of mollusks.

In spite of these investigations, mollusks in tropical and subtropical regions, especially in sheltered beaches, are still considered to be poorly studied. Moreover, data from temperate regions are sometimes conflicting, especially in regard to species diversity. Knowledge of the species distribution of mollusks is very important for managers of economic activities and marine monitoring programs. The aim of the present work was to provide data on the intertidal zonation of mollusks in sheltered beaches in Caraguatatuba Bay and São Sebastião Channel, as well as to evaluate the influence of environmental variables.

\section{MATERIAL AND METHODS}

Field samples were taken monthly between August 1995 and July 1997 at low spring tides in Enseada, Araçá and Barra Velha beaches. Enseada Beach is located in Caraguatatuba Bay, and Araçá and Barra Velha beaches in the São Sebastião Channel on the northern coast of São Paulo State (Fig. 1). Because these beaches are located near urban centers and an important oil terminal, they are continuously exposed to low levels of sewage runoff and to the risk of oil spills.

One study sector was selected in Enseada and Barra Velha beaches, and two sectors in Araçá (Araçá I and Araçá II). The sectors were $10 \mathrm{~m}$ wide and equivalent in length to the width of the intertidal zone. Each sector was divided into three horizontal levels: lower intertidal, the region nearest the water line during low tide; upper intertidal, adjacent to the dry zone; and middle intertidal, the region between the two former ones. The extension of each level was established by visually estimating the slope, the degree of water saturation, and consequently the air exposure period. One $10 \times 10 \mathrm{~m}$ sampling area was randomly chosen in each level; each sampling area was also subdivided in 1-m intervals.

The quantitative macrofauna samples were taken with a cylinder corer with a base area of $0.16 \mathrm{~m}^{2}$ inserted $20 \mathrm{~cm}$ deep. Three samples were taken in each level/month (nine samples per sector/month). Sampling units for each month were determined with the aid of a random-number table. The sediment was immediately washed in situ in a $1.0 \mathrm{~mm}$-mesh nylon bag. The remaining sediment was washed in the laboratory with seawater in sieves of $1.0 \mathrm{~mm}$ mesh. Mollusks were preserved in $70 \%$ alcohol, identified to species level and counted. In Enseada Beach, the samples were taken from August 1995 through July 1996; in Barra Velha, from August 1995 through December 1996; in Araçá I, from August 1995 through February 1997; and in Araçá II, from August 1996 through July 1997.

In order to characterize the intertidal environment in these areas, some environmental variables were sampled: salinity (interstitial water), grain size, silt-clay percentage, organic matter and calcium carbonate content of the sediment. The sediment characterization was done using three replicates,

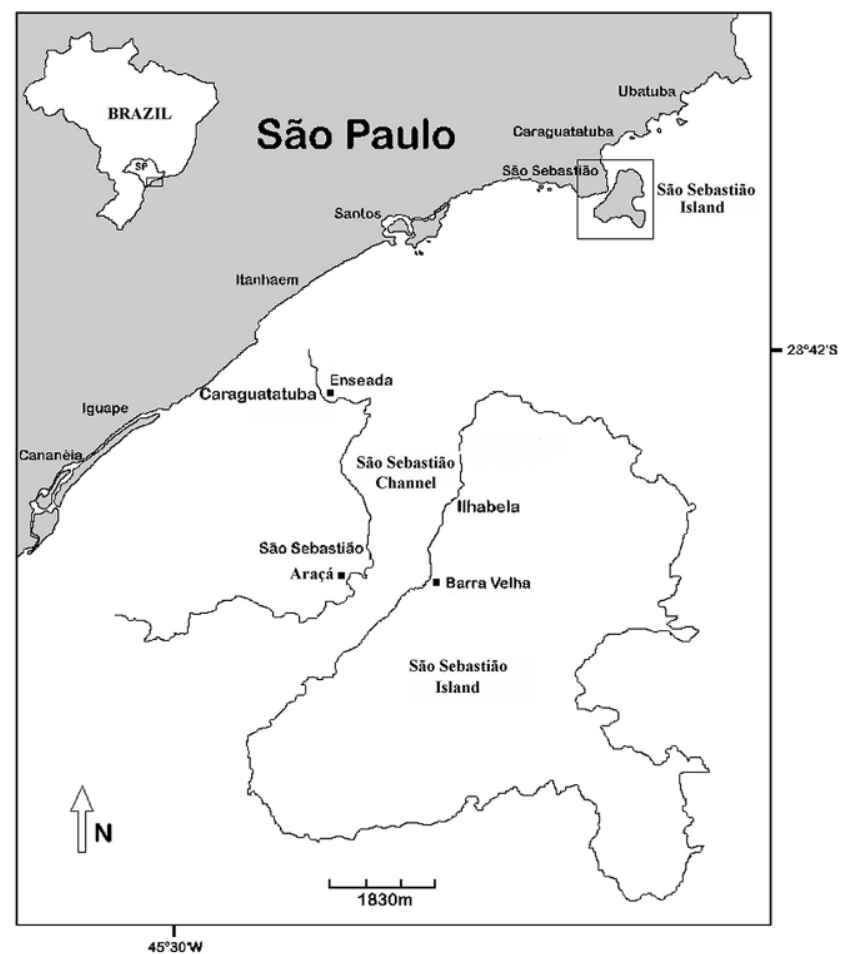

Figure 1. Locations of the three beaches studied: Enseada, in Caraguatatuba Bay; and Barra Velha and Araçá, on the São Sebastião Channel, in São Paulo State, Brazil.

and the salinity using five replicates taken quarterly in each level. Salinity was analyzed with a Goldberg T/C - Model 1041 portable refractometer, grain size by the Suguio method (SUGUiO 1973), and organic matter and carbonate contents of the sediment by the methods described by Amoureux (1966). The slope of study sectors was evaluated with a transparent hose filled with water.

Two-way analysis of variance (ANOVA) was performed to compare the environmental variables among the levels according to season (values of $\mathrm{p}<0.05$ were considered significant). This analysis was followed by Tukey's test to access pairwise comparisons between these variables. The diversity and evenness was estimated using the Shannon-Wiener index (index $\log _{2}$ ) and the Pielou index (KreBs 1989) for each level by sector using the total number of individuals. A graph of the cumulative number of species by month was made to verify whether the number of samples in each sector was sufficient to establish richness. Canonical Correspondence Analysis [performed by HiLL's (1979) method] was used to analyze the influence of environmental variables on the spatial patterns of species distribution. For this multivariate analysis, mean values of the environmental variables were used to characterize each level according to season, and a biological matrix was constructed using levels/seasonally pooled data for the most abundant species, standardized to an area of $0.16 \mathrm{~m}^{2}$. Spatial distribution was also investigated by subdividing each $10 \times 10$ $\mathrm{m}$ area sampled into $1 \mathrm{~m}$ vertical levels, and noting the densities 

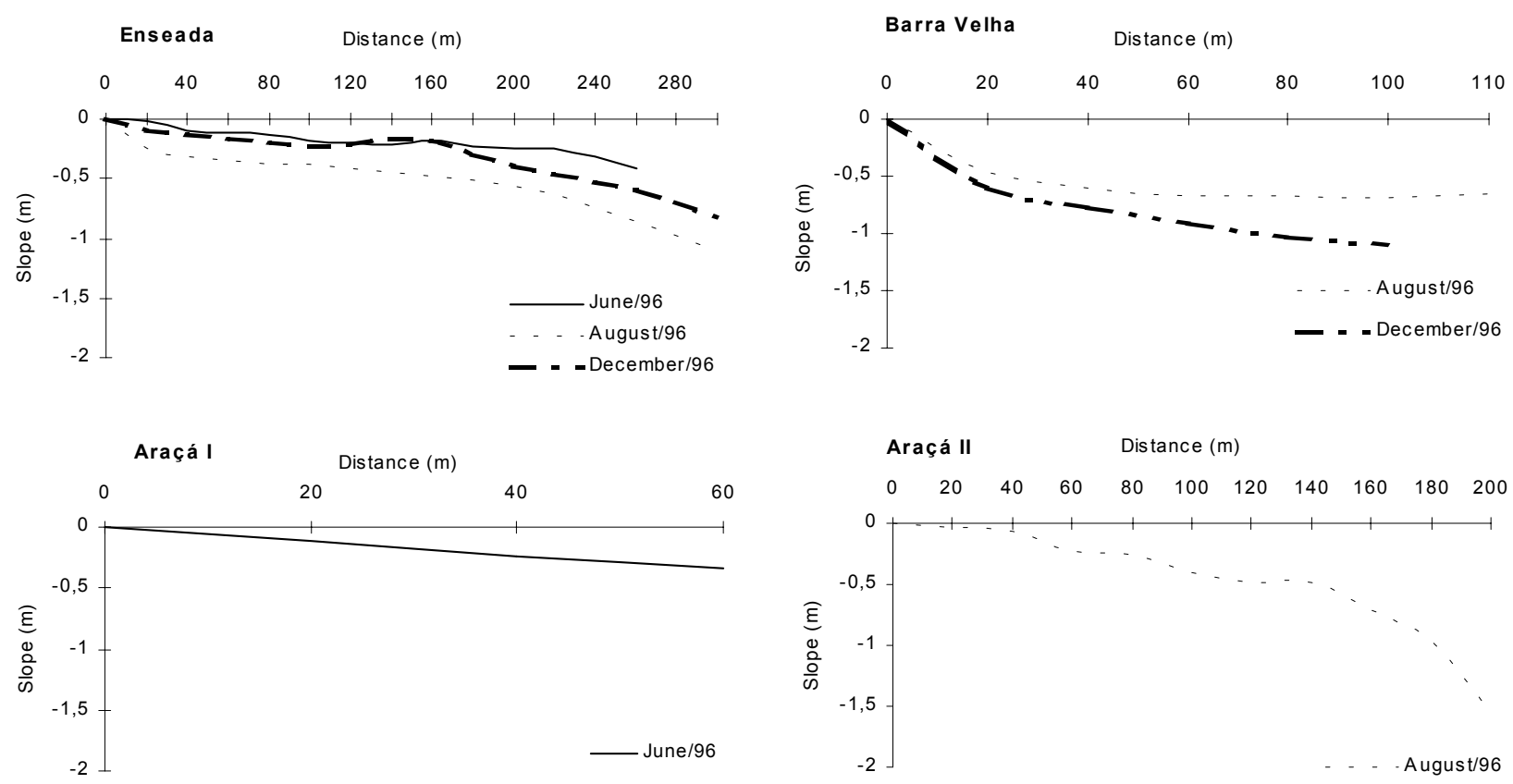

Figure 2. Intertidal slopes of the four study sectors: Enseada, Barra Velha, Araçá I and Araçá II.

of the most abundant species in each levels. Since not all the environmental variables followed a normal distribution, the data were $\log _{10}$-transformed prior to statistical analysis.

\section{RESULTS}

The Enseada, Barra Velha, Araçá I and Araça II sectors are very sheltered environments with a gentle slope (Fig. 2) and substrate composed of fine and very fine sand (Tab. I). The mean values of environmental variables, and the results of the analysis of variance and Tukey's test are shown in table I. Environmental variables did not clearly discriminate the levels in the sectors. In the Enseada sector, salinity was significantly different among levels in winter, spring and summer, being lowest in the upper level; and calcium carbonate content was significantly different in spring, summer and autumn, being highest in the low level. In Barra Velha, silt-clay, organic matter content and sorting coefficient were higher than in other sectors. The sediment grain size and sorting coefficient were significantly different among levels in spring and summer. The sediment in Barra Velha varied from fine to very fine sand, and the high sorting coefficient indicated that the sediment was poorly sorted. Calcium carbonate and organic matter content were significantly different among the levels of the Araçá I sector. Calcium carbonate was higher in the middle level, and organic matter content was higher in the lower level of the Araçá I sector. In Araçá II, the environmental variables were similar among levels. Nevertheless, the sorting coefficient ranged from moderately sorted in the lower and middle levels to poorly sorted in the upper level in winter, spring and summer. Organic matter content differed significantly between summer and autumn.
In general, richness, diversity and evenness tended to be higher in the lower levels in all sectors (Tab. II). The highest values of diversity and evenness were found in the lower level of Barra Velha, and the lowest in the upper level of Enseada. Cumulative species number eventually stabilized in the Enseada, Barra Velha and Araçá II sectors, but tended to increase in Araçá I (Fig. 3).

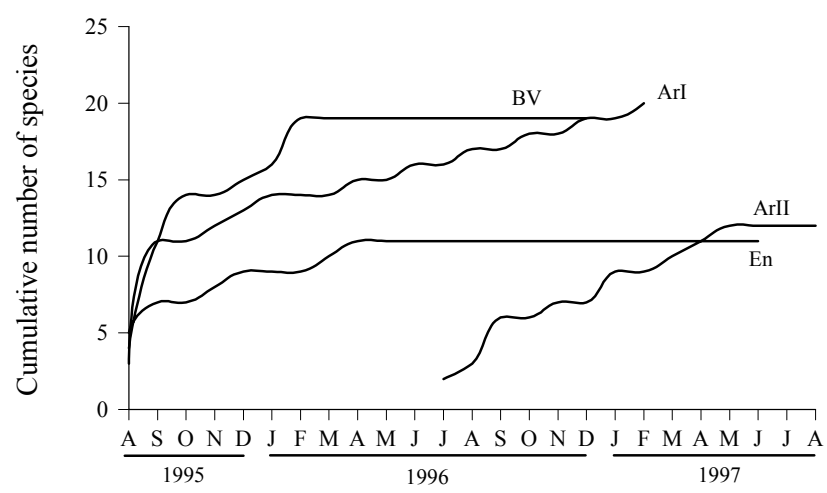

Figure 3. Cumulative number of species by month and sector. (En) Enseada, (BV) Barra Velha, (Arl) Araçá I, (Arll) Araçá II.

The distribution of the most abundant species of mollusks along the sectors is shown in figures $4,5,6$ and 7 . Faunal zonation was more evident in the Enseada, Araçá I and Araçá II sectors than in the Barra Velha sector. In general, the

Revista Brasileira de Zoologia 20 (2): 291-300, junho 2003 


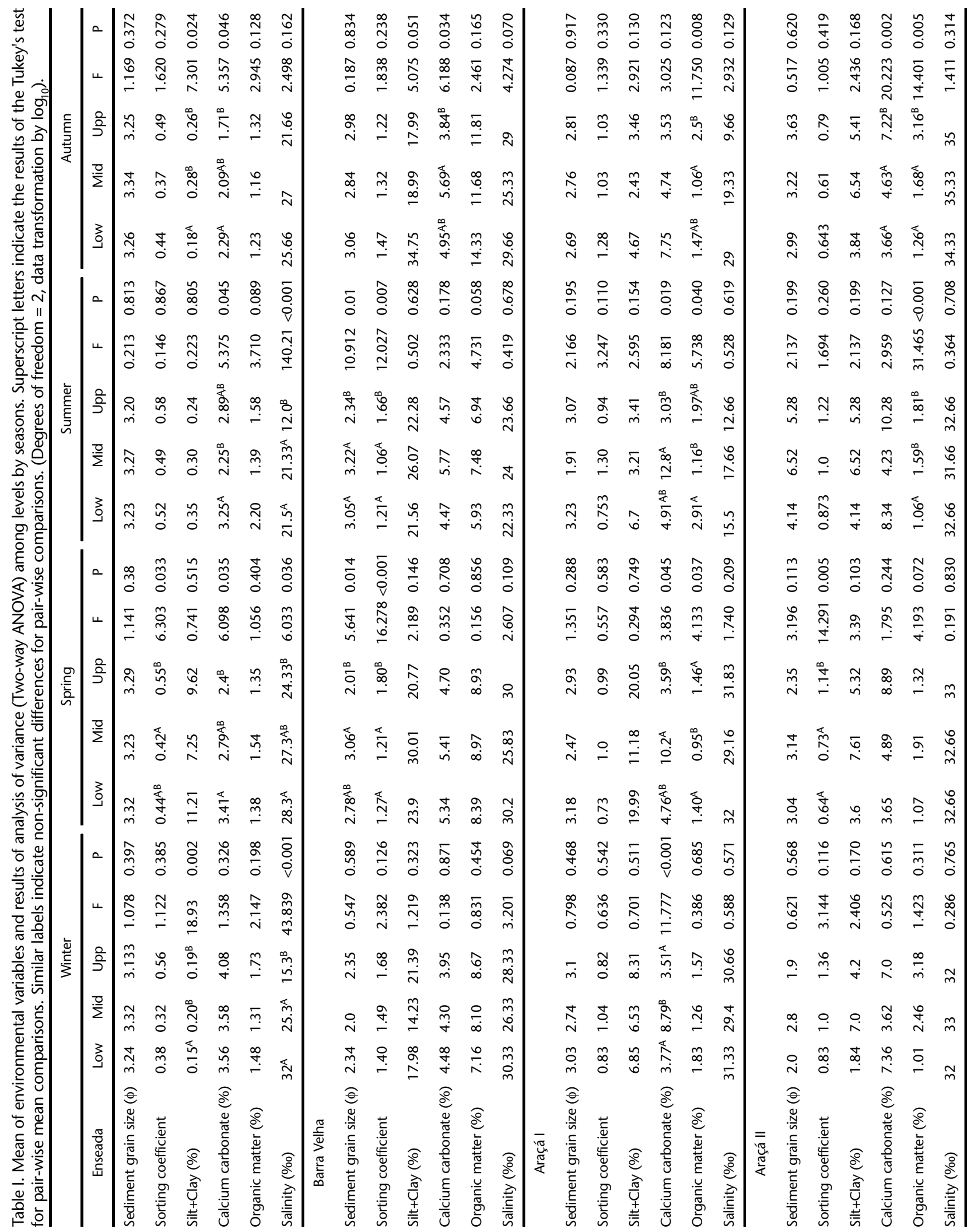

Revista Brasileira de Zoologia 20 (2): 291-300, junho 2003 
Table II. Occurrence, density (ind./0.16 $\mathrm{m}^{2}$ ), richness, diversity and evenness of mollusks in the three levels of study sectors: Enseada, Barra Velha, Araçá I and Araçá II. (Low) Lower level, (Mid) middle level, (Upp) upper level.

\begin{tabular}{|c|c|c|c|c|c|c|c|c|c|c|c|c|}
\hline \multirow{2}{*}{$\begin{array}{c}\text { Sectors } \\
\text { Species/Level }\end{array}$} & \multicolumn{3}{|c|}{ Enseada } & \multicolumn{3}{|c|}{ Barra Velha } & \multicolumn{3}{|c|}{ Araçá I } & \multicolumn{3}{|c|}{ Araçá II } \\
\hline & Low & Mid & Upp & Low & Mid & Upp & Low & Mid & Upp & Low & Mid & Upp \\
\hline \multicolumn{13}{|l|}{ Cerithiidae } \\
\hline Certhium atratum (Born, 1778) & & & & & & & & & & 1.27 & 0.027 & \\
\hline \multicolumn{13}{|l|}{ Nassariidae } \\
\hline Nassarius vibex (Say, 1822) & & & & 0.04 & 0.06 & & 0.01 & 0.01 & & 0.027 & & \\
\hline \multicolumn{13}{|l|}{ Olividae } \\
\hline Olivella minuta (Link, 1807) & 0.51 & & & & & & 0.64 & 0.35 & 0.27 & 3.22 & 2.97 & 0.13 \\
\hline \multicolumn{13}{|l|}{ Arcidae } \\
\hline Anadara ovalis (Bruguiere, 1789) & & & & & 0.02 & & & 0.01 & & & & \\
\hline \multicolumn{13}{|l|}{ Lucinidae } \\
\hline Codakia orbiculata (Montagu, 1808) & & & & 0.08 & & & & & & & & \\
\hline Codakia costata (Orbigny, 1848) & & & & 0.02 & & & & & & & & \\
\hline Lucina pectinata (Gmelin, 1791) & & & & 0.20 & 0.22 & 0.12 & & 0.01 & & & & \\
\hline Diplodonta punctata (Say, 1822) & & & & & & & 0.03 & & & 0.08 & & \\
\hline \multicolumn{13}{|l|}{ Mactridae } \\
\hline Mulinia cleryana (Orbigny, 1846) & 0.03 & & & & & & & & & & & 0.05 \\
\hline \multicolumn{13}{|l|}{ Tellinidae } \\
\hline Tellina sp. 1 & & & & 0.02 & & & & & & & & \\
\hline Tellina sp. 2 & & & & 0.04 & 0.02 & & & & & & & \\
\hline Tellina lineata Turton, 1819 & & 0.06 & & 0.06 & 0.02 & 0.02 & 0.09 & 0.18 & 0.09 & 0.05 & 0.05 & 0.11 \\
\hline Tellina versicolor De Kay, 1843 & & & & 0.37 & 0.45 & 0.02 & & 0.01 & & 0.08 & & \\
\hline Strigilla carnaria (Linnaeus, 1758) & 0.03 & 0.03 & & & & & 0.03 & & & 0.027 & & \\
\hline Macoma urugayensis (E. A. Smith, 1885) & & & & 0.04 & 0.04 & & 0.01 & & & & & \\
\hline Macoma constricta (Bruguìere, 1792) & & & 0.09 & 0.14 & 0.18 & 0.5 & & 0.01 & 0.20 & & 0.11 & 0.027 \\
\hline \multicolumn{13}{|l|}{ Semelidae } \\
\hline Abra lioica (Dall, 1881) & & & & 0.04 & 0.04 & 0.02 & & & & & 0.027 & \\
\hline Semele proficua (Pulteney, 1799) & & & & & & & & & & 0.16 & & \\
\hline \multicolumn{13}{|l|}{ Psammobiidae } \\
\hline Tagelus plebeius (Lighfoot, 1786) & & 0.03 & 1.57 & 0.04 & 0.02 & 0.04 & & & 0.01 & & & 0.08 \\
\hline Tagelus divisus (Spengler, 1794) & & 0.03 & & 0.33 & 0.52 & 0.16 & 0.03 & & 0.03 & & 0.08 & \\
\hline \multicolumn{13}{|l|}{ Donacidae } \\
\hline Donax gemmula Morrison, 1971 & & & & & & & 0.01 & & & & & \\
\hline \multicolumn{13}{|l|}{ Veneridae } \\
\hline Chione cancellata (Linnaeus, 1767) & & & & & & & & & & 0.08 & 0.027 & \\
\hline Anomalocardia brasiliana (Gmelin, 1791) & & 0.21 & 0.06 & 0.16 & 0.25 & 0.68 & 0.57 & 0.90 & 0.55 & 0.66 & 2.27 & 1.69 \\
\hline Tivela mactroides (Born, 1778) & 0.12 & & & & & & & & & & & \\
\hline \multicolumn{13}{|l|}{ Corbulidae } \\
\hline Corbula caribaea Orbigny, 1842 & 0.03 & & & & 0.04 & & 0.11 & 0.01 & & 0.36 & 0.80 & 0.08 \\
\hline Corbula sp. & & & & & & & 0.11 & & 0.01 & 0.05 & 0.05 & \\
\hline \multicolumn{13}{|l|}{ Periplomatidae } \\
\hline Periploma ovata Orbigny, 1846 & & & & & & & & & & 0.027 & & \\
\hline Density (ind. / $0.16 \mathrm{~m}^{2}$ ) & 0.72 & 0.36 & 62 & 1.87 & 1.62 & 1.58 & 1.92 & 1.55 & 1.21 & 6.14 & 6.44 & 2.19 \\
\hline Richness & 5 & 5 & 3 & 14 & 13 & 8 & 11 & 9 & 7 & 13 & 10 & 7 \\
\hline Diversity & 1.356 & 1.781 & 0.483 & 3.209 & 2.896 & 2.064 & 2.374 & 1.761 & 2.061 & 2.126 & 1.911 & 1.021 \\
\hline Evenness & 0.584 & 0.767 & 0.305 & 0.843 & 0.782 & 0.688 & 0.686 & 0.555 & 0.734 & 0.575 & 0.552 & 0.395 \\
\hline
\end{tabular}



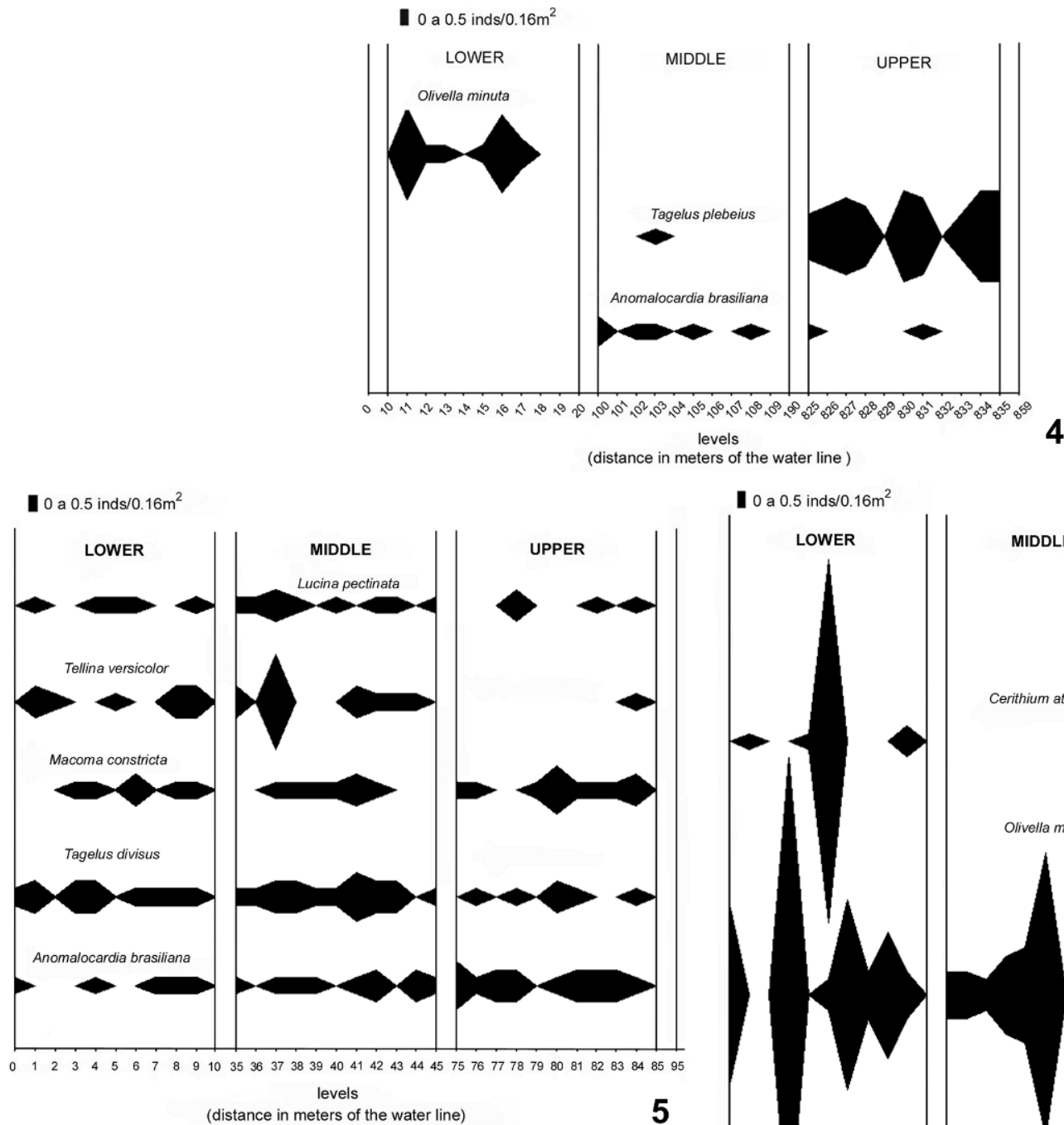

0 a 0.5 inds $/ 0.16 \mathrm{~m}^{2}$

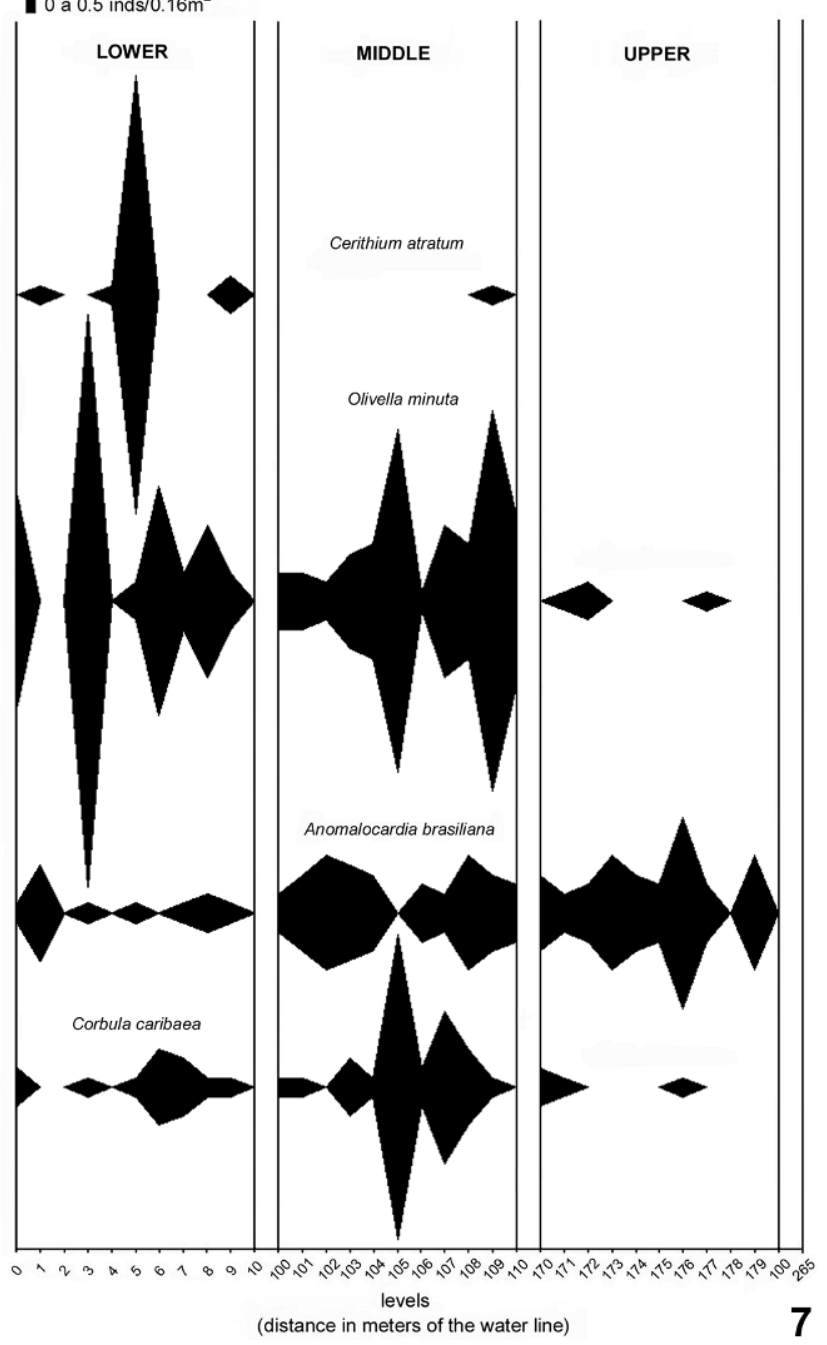

0 a 0.5 inds $/ 0.16 \mathrm{~m}^{2}$

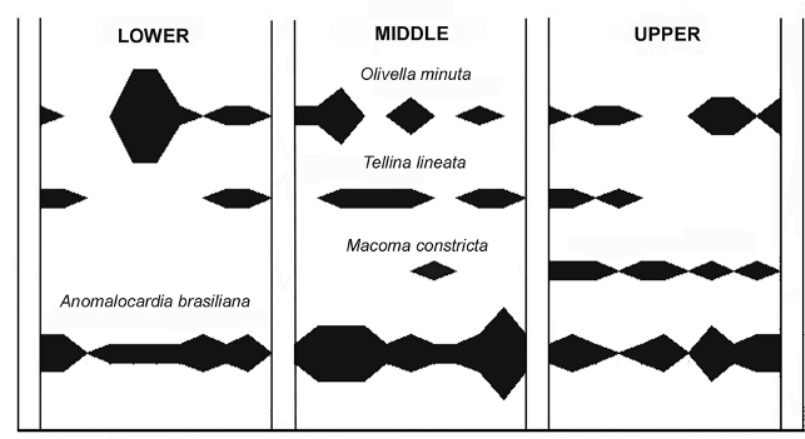

$0 \quad 10111213141516171819203536373839404142434445555657585960616263646570$ levels

(distance in meters of the water line)

Figures 4-7. Zonation of the most abundant species in all levels (lower, middle and upper) of the: (4) Enseada sector, (5) Barra Velha sector, (6) Araçá I sector, and (7) Araçá II sector.

Revista Brasileira de Zoologia 20 (2): 291-300, junho 2003 
mollusks were distributed within the sectors as follows: a) Enseada: Olivella minuta (Link, 1807) abundant in the lower level and Tagelus plebeius (Lightfoot, 1786) in the upper level; b) Barra Velha: Tagelus divisus (Spengler, 1794), Tellina versicolor De Kay, 1843 and Lucina pectinata (Gmelin, 1791) abundant in the lower and middle levels, Anomalocardia brasiliana (Gmelin, 1791) and Macoma constricta (Brugüìere, 1792) abundant in the upper level; c) Araçá I: Olivella minuta abundant in the lower level; Tellina lineata Turton, 1819 occurring in the middle level and $A$. brasiliana abundant in all three levels, principally in the middle level; d) Araçá II: Cerithium atratum (Born, 1778) abundant in the lower level, O. minuta in the lower and middle levels, Corbula caribaea Orbigny, 1842 in the middle level and A. brasiliana abundant in the middle and upper level; d) Anomalocardia brasiliana occurred in all four sectors and in all levels, except in the lower level in the Enseada sector.

Canonical Correspondence Analysis was used to determine the relationship among species distribution and the environmental variables (Fig. 8). In Enseada, 51.5\% of the total was explained by axis 1 , and $16.5 \%$ by axis 2 . The species $T$. plebeius occurred at sites with low salinity and well sorted sediment. In Barra Velha, axis 1 explained $36.7 \%$ of the total variance and axis 2 explained $11.8 \%$. Salinity, silt-clay and sorting coefficient seem to play an important role in the species distribution, contrasting with a lesser influence of organic matter, grain size and calcium carbonate. The occurrence of Lucina pectinata, $T$. divisus and $T$. versicolor was associated with high silt-clay and calcium carbonate contents. The species $M$. constricta and $A$. brasiliana occurred in environments with high sorting coefficient and salinity. In Araçá I, $44.3 \%$ of the total was explained by axis 1, and $11.3 \%$ by axis 2 , while in Araçá II axis 1 explained $37.3 \%$ and axis 2 explained 24.6\%. In Araçá I, calcium carbonate content and salinity showed a better correlation with the distribution of mollusks and in Araçá II, calcium carbonate, salinity, silt-clay and organic matter seem to play an important role in species distribution. In these two sectors $O$. minuta occurred at sites with high salinity and with moderately sorted sediment, and $T$. lineata and $A$. brasiliana occupied environments with high calcium carbonate and poorly sorted sediment. Tellina lineata and M. constricta were also associated with high organic matter content in the Araçá II sector. In Araçá I, the occurrence of M. constricta was also associated with high values of sorting coefficient, and in Araçá II C. caribaea occurred at a site with high salinity and silt-clay.

\section{DISCUSSION}

The study sectors are protected from wave action and have fine and very fine sand predominating. Canonical Correspondence Analysis showed that silt-clay, sorting coefficient, organic matter content, calcium carbonate and salinity played an important role in the distribution of species, contrasting with the lesser influence of mean grain size. According to RHOADs (1974), grain size is one of the main factors influencing the distribution of macrofauna. Although numerous studies have supported the animal-sediment hypothesis, there is little evidence that sedimentary grain size alone is the primary determinant of infaunal species distributions (SNelgrove \& ButMan 1994).

In the Barra Velha, Araçá I and Araçá II sectors, diversity increased from the upper toward the lower levels, confirming the results found by many investigators (McLaCHLAN 1990, Rizzo \& AMARAL 2001). Olivella minuta showed clear zonation patterns, being more abundant in the lower levels, especially in the Araçá I and Araçá II sectors. This pattern may be related to more sediment moisture at the lower level and less desiccation. According to SмIтH (1977), the moisture content in sand at low tide and the grain size influence animals to burrow. EDWARDS (1969) observed that larger individuals of O. biplicata (Sowerby, 1825) can tolerate longer exposure to dry air than can small ones. Olivella minuta probably cannot tolerate longer exposure to dry air. The high salinity in the lower levels may also have influenced the distribution of O. minuta. Physical and chemical factors such as salinity and temperature may influence zonation patterns in sandy beaches and mudflats (КоH \& SHIN 1988). The time of exposure to dry air tends to be longer in sandflats, creating well-defined gradients of temperature and salinity. The Enseada sector, located in a tide flat, showed a clear salinity gradient. The upper level of this sector was characterized by high densities of Tagelus plebeius and low salinity. This species tolerates wide variations of salinity and is commonly found in estuaries (Holland \& DeAn 1977).

Anomalocardia brasiliana occurred widely, but reached its highest population densities in sites with poorly sorted sediments rich in calcium carbonate and organic matter, as in the upper levels of Araçá II and Barra Velha. In the Enseada sector this species occurred predominantly in the middle level, and in the Araçá I sector it was abundant in all levels. DenadaI \& AMARAL (1999) also observed that A. brasiliana tended to occur in environments rich in calcium carbonate and organic matter. Netto \& Lana (1995) found A. brasiliana in the highest level in Paranaguá Bay, while the highest organic matter contents were recorded in the lower level. Nevertheless, the organic matter contents recorded by NetTo \& LANA (1995) were higher than those recorded by DenadaI \& AMARAL (1999) and in the present study. Lopes \& Schaeffer-Novelli (1992) observed that $A$. brasiliana only occurred in the intertidal zone in Saco da Ribeira Beach. This species can tolerate wide environmental variations. It is euryhaline (LEONEL et al. 1982), can survive in anoxic environments, and occurs in different types of sediment (SCHAefFer-Novelli 1980).

Macoma constricta reached its highest population densities in sites with poorly sorted sediments rich in organic matter, as in the upper level of Barra Velha. According to Snelgrove \& Butman (1994), organic matter may be an important causal factor because organic matter is a primary source of food for deposit-feeders and indirectly for suspension-feeders. Although organic matter may not be the only variable determining the distribution of $M$. constricta, it does play an important role.

Although the availability of food was not analyzed, this factor may influence the distribution of the mollusks. The herbivorous gastropod Cerithium atratum occurred only in the Araçá II sector, where there was seaweed on the sediment. LOPES $\&$ SCHAEFFER-Novelli (1992) found this species near rocky shores where seaweed was growing. Cerithium atratum showed no tendencies related to sediment type or tide level. There are reports of C. atratum occurring on both rocky and soft-bottom shores, in the intertidal and sublittoral zones (LOPES \& SCHAEFFERNovelui 1992).

Biological factors such as recruitment, predation and competition are important in the establishment and mainte-

Revista Brasileira de Zoologia 20 (2): 291-300, junho 2003 


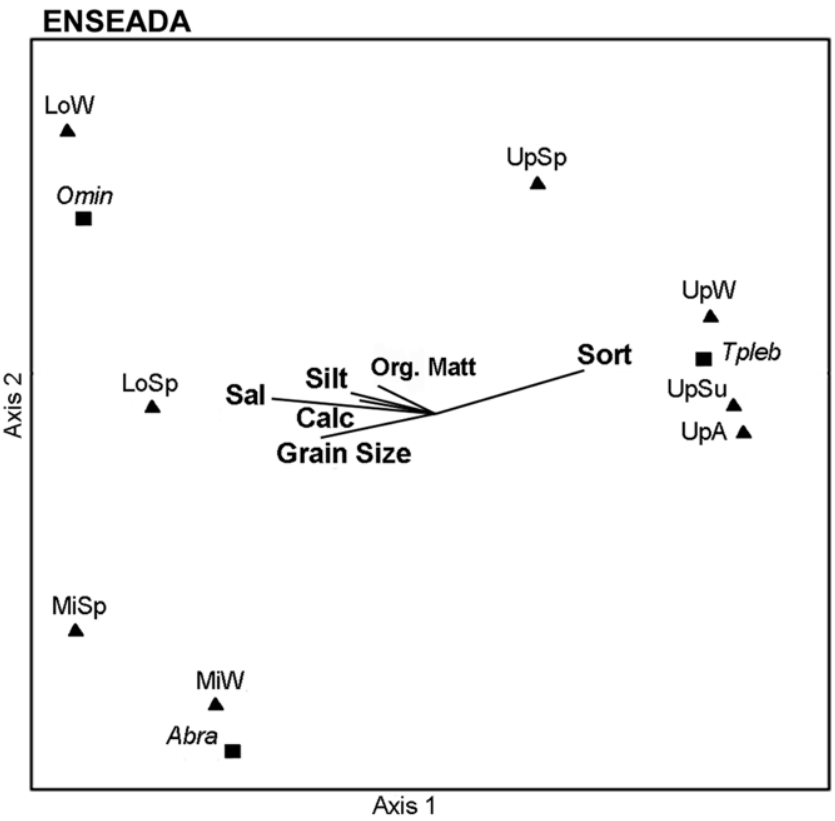

\section{BARRA VELHA}

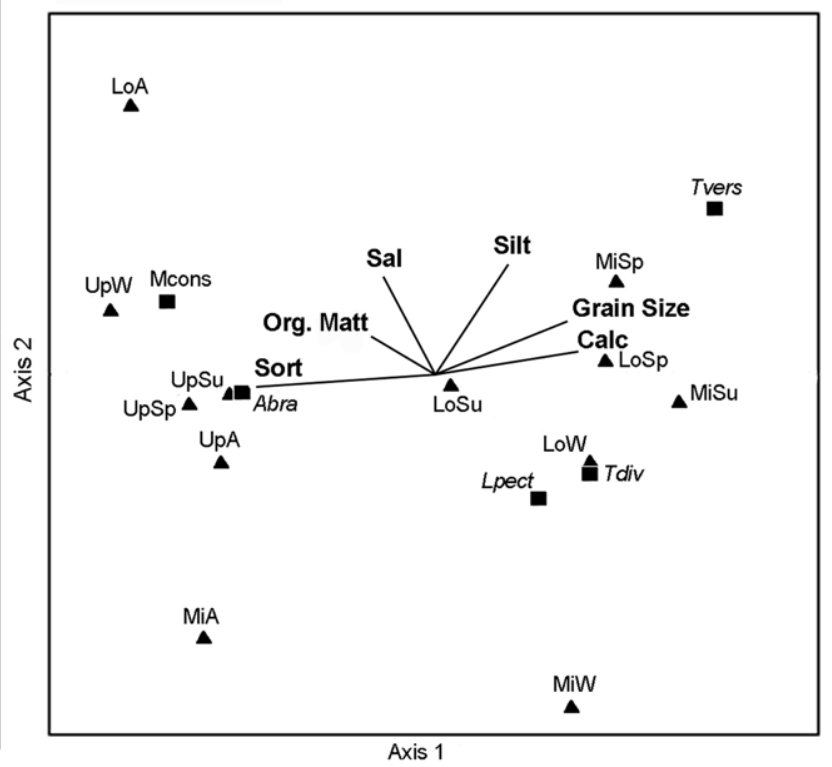

ARAÇA I
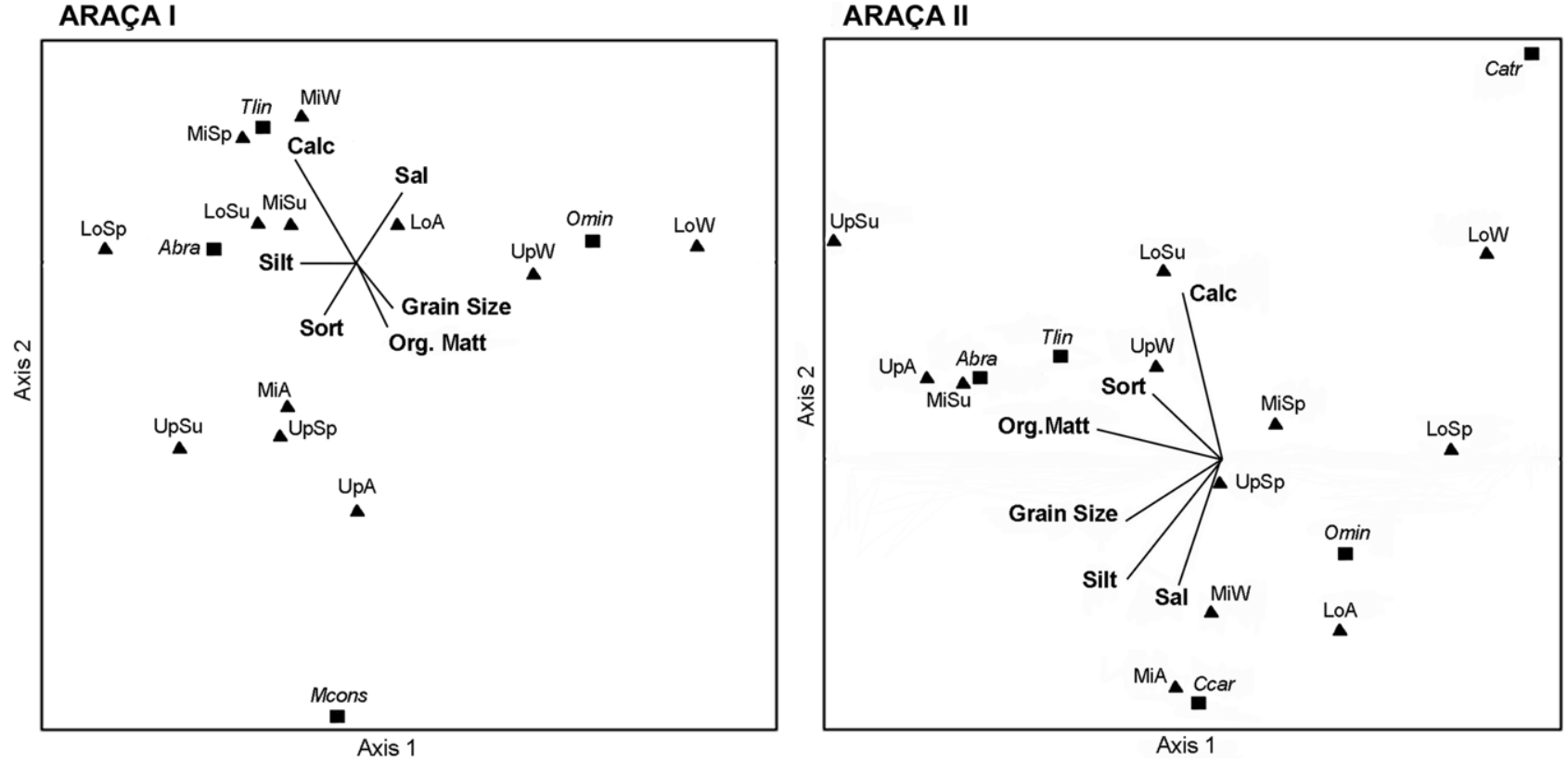

Figure 8. Canonical Correspondence Analysis (CCA) of the most abundant species and levels/seasons in relation to certain environmental variables in the Enseada (A), Barra Velha (B), Araçá I (C) and Araçá II (D) sectors, (Org. Mat) organic matter content, (Silt) silt-clay, (Sort) sorting coefficient, (Cal) calcium carbonate content, (Grain Size) mean grain size, (LoW) low/winter, (MiW) middle/winter, (UpW) upper/winter, (LoSp) low/spring, (MiSp) middle/spring, (UpSp) upper/spring, (LoSu) low/summer, (MiSu) middle/summer, (UpSu) upper/summer, (LoA) low/autumn, (MiA) middle/autumn, (UpA) upper/autumn, (Tpleb) Tagelus plebeius, (Tdiv) Tagelus divisus, (Tlin) Tellina lineata, (Tvers) Tellina versicolor, (Abra) Anomalocardia brasiliana, (Omin) Olivella minuta, (Mcons) Macoma constricta, (Ccar) Corbula caribaea, (Lpect) Lucina pectinata, (Catr) Cerithium atratum. The low and midle levels of summer and autumn in the Enseada sector were not included in the analysis because in these levels not any species were collected.

Revista Brasileira de Zoologia 20 (2): 291-300, junho 2003 
nance of zonation on rocky shores. On soft-bottom shores, however, the factors controlling communities are not necessarily the same as on rocky shores, and there are fewer studies of the influence of biological factors in these communities. Detection of intra- and interspecific competition is very complex for two main reasons: the inherent difficulties in experimentally manipulating the generally small and mobile infauna, and the three-dimensional structure of the habitat, which enables horizontal and vertical space partitioning (Wilson 1991 apud Defeo et al. 1997). According to McLachlan \& JARAMILLO (1995), because of this mobility, larval recruitment is less critical in establishing or maintaining zones than for sessile species on rocky shores, and predation and competition for food are the only biological factors that are likely to be important in affecting zonation in sandy beaches.

Biological zones are valid if they include the center of gravity of at least one characteristic species, and should be percepible without recourse to sophisticated statistical techniques (McLaChlan \& JaRAMILlo 1995). Biological zones in sandy beaches, however, are not as clearly defined, as a consequence of the dynamic environment of the beach. Biological zones are clearest in the upper beach, and also tend to be narrowest at the upper shore and to widen downshore, because the concave slope of most beaches results in more gradual horizontal changes, associated with the intertidal gradient toward the lower shores (MCLACHLAN \& JARAMILLO 1995).

DAHL (1952), studying the crustacean fauna, established three zones: supralittoral, midlittoral and sublittoral. SALVAT (1964) established four zones, defined on the basis of water content, from high to low beach levels: dry sand zone; retention zone, where the sediment retains a small amount of water; resurgence zone, where water circulates among the sand grains, and saturation zone, where the sediment is constantly saturated by water.

In the present study, the beach sectors could be divided into two biological zones. In the upper zone, which corresponds to the highest part of the midlittoral described by DAHL (1952) and to the retention zone of SaLvat (1964), the species T. plebeius, $A$. brasiliana and $M$. constricta were more abundant. In the lower zone, which is equivalent to the resurgence zone of SALVAT (1964), O. minuta, T. lineata, C. caribaea, C. atratum, T. divisus, $T$. versicolor and $L$. pectinata were more abundant. The middle level included the upper part of the lower zone, and the transition zone between lower and upper. Denadai et al. (2001), studying the zonation of the mollusks in the midlittoral of São Franscisco Beach, established two biological zones: upper, in which $A$. brasiliana dominated; and lower, in which $C$. atratum, C. caribaea, Tegula viridula (Gmelin, 1791), Codakia orbiculata (Montagu, 1808), Semele proficua (Pulteney, 1799) and Chione subrostrata (Lamarck, 1818) were abundant.

The equivalence between the schemes of Dahl and Salvat is evident, but there is some disagreement. BALLY (1983) believed that the resurgence and saturation zones of Salvat correspond to the sublittoral of Dahl. Other researchers conceived of the resurgence zone as part of the midlittoral of Dahl (McLachlan 1990, Rafaelli et al. 1991, Jaramillo \& Gonzalez 1991). According to MCLACHLAN (1990), resurgence zone species are intertidal forms that require wet sand during low tide, while retention zone species are also intertidal forms, but are capable of remaining in sand that is only slightly damp during the low tide period. In the sectors studied, the resurgence zone species (lower zone) occurred nearest to the water line, and their distribution may extend to the sublittoral.

Although beach zones are not clearly defined, there is evidence that the subdivision of the intertidal region into biological zones can be observed in many sandy beaches. Independent of the different opinions and nomenclature, the intertidal region of Enseada, Barra Velha, Araçá I and Araçá II sectors could be differentiated into two zones, in which the lower level showed higher diversity and richness. The results obtained in the present work show that the heterogeneous sediment, the organic matter content, and salinity were important for distribution of the mollusk community. Moreover, the distributions of some species could be related to variations in tide level and the availability of food.

\section{ACKNOWLEDGMENTS}

We wish to express our sincere thanks to É. Soares Marinho, A. Máximo Rosa (UNICAMP) and to CEBIMar technicians who assisted in the field work. We are particularly grateful to the "Centro de Biologia Marinha (CEBIMar - USP)" and the "Departamento de Zoologia - IB/UNICAMP" for logistical support, and Dr. J. W. Reid for revision of the English text. This reasearch was supported by grants from the "Fundação de Amparo a Pesquisa do Estado de São Paulo (FAPESP)" and from "Fundo de Apoio a Pesquisa (FAEP UNICAMP)".

\section{REFERENCES}

Amaral, A.C.Z.; E.H. Morgado; P.P. Lopes; L.F. Belúcio; F.P.P. Leite \& C.P. Ferreira. 1990. Composition and distribution of the intertidal macrofauna of sandy beaches on São Paulo coast. In: Anais do Simpósio de Ecossistemas da Costa Sul e Sudeste - Estrutura, Função e Manejo, 2, Águas de Lindóia. Publ. ACIESP, São Paulo 3 (71): 258-279.

Amoureux, L. 1966. Étude bionomique et écologique de quelques annélides polyquetes des sables intetidaux de côtes ouest de la France. Archs. Zool. exp. gén., Roscoff, 107: 1-218.

BALLY, R. 1983. Intertidal zonation on sandy beaches of the west coast of South Africa. Cah. Biol. Mar., Roscoff, 24 (1): 85103.

Borzone, C.A. 1994. Distribución de la malacofauna en el infralitoral de una playa arenosa expuesta del sur del Brasil. Rev. Invest. Cient. Auton. Baja Calif. Sur., Ser. Cienc. Mar., La Paz, 5: 23-36.

Borzone, C.A.; J.R.B. SOUZA \& A.G. SOARES. 1996. Morphodynamic influence on the structure of inter and subtidal macrofaunal communities of subtropical sandy beaches. Rev. Chil. Hist. Nat., Santiago, 69: 565-577.

Brown, A.C. \& A. McLachlan. 1990. Ecology of Sandy Shores. New York, Elsevier Science, 328p.

Corbisier, T.N. 1991. Benthic macrofauna of sandy intertidal zone at Santos Estuarine System, São Paulo, Brazil. Boletim do Instituto Oceanográfico, São Paulo, 39 (1): 1-13.

DAHL, E. 1952. Some aspects of the ecology and zonation of fauna on sandy beaches. Oikos, Lund, 4 (1): 1-27.

Defeo, O.; A. Brazeiro; A. de Alava \& G. Riestra. 1997. Is sandy beach macrofauna only physically controlled? Role of substrate and competition in isopods. Estuar. Coast. Shelf 
Sci., London, 45: 453-462.

Denadai, M.R. \& A.C.Z. Amaral. 1999. A comparative study of intertidal molluscan communities in sandy beaches, São Sebastião Channel, São Paulo State, Brazil. Bull. mar. Sci., Miami, 65 (1): 91-103.

Denadai, M.R.; A.C.Z. Amaral \& A. Turra. 2001. Spatial distribution of molluscs in two anthropogenic mixed sandrock substrates of São Sebastião Channel, São Paulo State, Brazil. Estuar. Coast. Shelf Sci., London, 53: 733-743.

EDWARDS, D.C. 1969. Zonation by size as an adaptation for intertidal life in Olivella biblicata. Am. Zool., Seattle, 9 (2): 399-417.

HiLL, M.O. 1979.Twinspan- A Fortran program for arranging multivariate data in a two way table by classification of the individual and attributes. Ithaca, Cornell University, $318 p$.

Holland, A.F. \& J.M. Dean. 1977. The biology of the stout razor clam Tagelus plebeius: I. Animal-sediment relationships, feeding mechanism and community biology. Chesapeake Sci., Salomons Island, 18 (1): 58-66.

Jaramillo, E. \& M. Gonzalez. 1991. Community structure and zonation of the macroinfauna along a dissipative-reflective range of beach category in Southern Chile. Stud. Neotrop. Fauna Environ., Lisse, 26 (4): 193-212.

Jaramillo, E.; A. McLachlan, \& P. Coetzee. 1993.Intertidal zonation patterns of exposed sandy beaches in south-central Chile. Mar. Ecol. Prog. Ser., Oldendorf, 101: 105-118.

Кон, C.H. \& H.C. SHIN. 1988. Environmental characteristics and distribution of macrobenthos in a mudflat of the west coast of Korea (Yellow Sea). Neth. J. Sea. Res., Den Helder, 22 (3): 279-290.

KREBS, C.J. 1989. Ecological Methodology. New York, Harper Collins, 654p.

Leonel, R.M.V.; A.R.M. Magalhães, \& J.E. Lunetta. 1982. Survival rate of Anomalocardia brasiliana (Gmelin, 1791) (MolluscaBivalvia) at different levels of salinity. Braz. J. Med. Biol. Res., Ribeirão Preto, 5 (4-5): 337.

Lopes, S.G.B.C. \& Y. Schaeffer-Novelli. 1992. Bivalves e gastrópodes do Saco da Ribeira, Ubatuba - São Paulo. I. Levantamento, distribuição das espécies e características ambientais. Boletim de Zoologia da Universidade de São Paulo,São Paulo, 13: 9-49.

MCLachlan, A. 1990. Dissipative beaches and macrofauna

Received in 30.IX.2002; accepted in 29.V.2003. communities on exposed intertidal sands. J. Coast. Res., West Palm, 6 (1): 57-71.

. 1996. Physical factors in benthic ecology: effects of changing sand particle size on beach fauna. Mar. Ecol. Prog. Ser., Oldendorf, 131: 205-217.

MCLaChlan, A. \& E. Jaramillo. 1995. Zonation on sandy beaches. Oceanogr. Mar. Biol. Annu. Rev., London, 33: 305-335.

NetTo, S.A. \& P.C. Lana. 1995. Zonação e estratificação da macrofauna bêntica em um banco areno-lodoso do setor eurihalino de alta energia da Baía de Paranaguá (Paraná, Brasil). Iheringia, Série Zoologia, Porto Alegre, 79: 27-37.

Raffaelli, D.; I. KaraKassis \& A. Galloway. 1991. Zonation schemes on sandy shores: a multivariate approach. J. Exp. Mar. Biol. Ecol., Amsterdam, 48: 241-253.

RHOADs, D.C. 1974. Organism-sediment relations on the muddy sea floor. Oceanogr. Mar. Biol. Annu. Rev., London, 12: 263-300.

Rizzo, A.E. \& A.C.Z. Amaral. 2001. Spatial distribution of annelids in the intertidal zone in São Seabastião Channel, Brazil. Sci. Mar., Barcelona, 65 (4): 323-331.

SALVAT, B. 1964. Les conditions hidrodinamiques interstitelle des sediments meubles intertidale et la repartition verticale de la genne endoyeé. A.C.R. Acad. Sci. Paris 259: 15671571.

Schaeffer-Novelli, Y. 1980. Análise populacional de Anomalocardia brasiliana (Gmelin, 1791), na Praia do Saco da Ribeira, Ubatuba, Estado de São Paulo. Boletim do Instituto Oceanográfico, São Paulo, 29 (2): 351-355.

SмITH, R.L. 1977. Elements of Ecology and Field Biology. New York, Harper \& Row Publishers, 197p.

Snelgrove, P.V.R. \& C.A. Butman. 1994. Animal-sediment relationships revisited: cause versus effect. Oceanogr. Mar. Biol. Annu. Rev., London, 32: 111-177.

SouZA, J.R.B. \& N.M. GianucA. 1995. Zonation and seasonal variation of the intertidal macrofauna on a sandy beach of Paraná State, Brazil. Sci. Mar., Barcelona, 59 (2): 103-111.

Suguio, K. 1973. Introdução à Sedimentologia. São Paulo, Edgard Blucher/Edusp, 312p.

WENDT, G. \& A. MCLaChlan. 1985. Zonation and biomass of the intertidal macrofauna along a South African sandy beach. Cah. Biol. Mar., Roscoff, 26: 1-14. 